\title{
EFFECT OF CAPITAL STRUCTURE ON RETURN ON EQUITY: A SURVEY ON ISSUERS OF CATEGORIES JII70 OF THE INDONESIA STOCK EXCHANGE
}

\author{
Badruzaman Jajang \\ Department of Accounting, Faculty of Economics, Universitiy of Siliwangi, Indonesia \\ Email: jajang.badruzaman@unsil.ac.id
}

\begin{abstract}
The research conducted in this study is the effect of the capital structure on return on equity, the survey was conducted on issuers in the JII70 with a sample of 32 issuers. The data taken are financial report data for 2016 and 2017. Based on the results of data processing with the SPSS version 25, it shows that the capital structure has a positive and significant effect on return on equity. This positive influence shows that effective use of debt will have an impact on return on equity increasing. But this increase in capital structure is a result of debt expansion. Therefore debt needs to be controlled and evaluated so that its use is effective which will ultimately have an impact on return on equity.
\end{abstract}

\section{KEY WORDS}

Capital structure, return on equity, financial report, survey, business.

Business risk is a very important indicator in determining the optimal capital structure. The business risk of each company will be different, this depends on the type of industry, thus the capital structure will vary greatly.

One of the important decisions faced by financial managers in relation to company operations is the decision on Capital Structure, namely financial decisions relating to the composition of debt, prefen shares and ordinary shares that must be used by the company.

Decision Capital Structure taken by the manager, not only affects the profitability of the company but also affects the risks faced by the company, because the capital structure contains the cost of debt and the cost of equity as a burden or risk for a company.

Capital Structure is a funding choice between debt and equity. Determination of the right capital structure will determine the success of a company in achieving its objectives. Determination of the size of capital requires the right solution so that available funds can maintain the continuity of the company.

Based on this background the researcher is interested in examining the effect of capital structure on return on equity, a survey of issuers in the category JII70.

\section{LITERATURE REVIEW}

Debt and capital are sources of corporate financing in carrying out company activities. The funding source is used by companies to purchase assets both current assets and fixed assets. In financing current assets, the source used comes from short-term debt, while financing for fixed assets comes from long-term debt and equity. The sources of financing both debt and equity require costs, because the source of financing must be used effectively and efficiently to produce maximum returns.

Various methods used to analyze the success of the company related to the effectiveness of the use of financing sources, one of which is return on equity, which measures the level of profits associated with invested capital or equity. Return On Equity $(\mathrm{ROE})$ is a ratio to measure net income after tax with own. Return On Equity is a measurement of income (income) that is available to the owners of the company (both ordinary shareholders and preferred shares) for the capital they invest into the company.

In general, the higher the return or return obtained, the better the value of the company and vice versa if the return or return obtained is low then the worse the value of the company. Thus ROE will determine the value of the company. Then the formula used to 
measure the performance is Return On Equity $(\mathrm{ROE})=$ Net profit after taxes / Shareholders' equity (Van Horne, James C., John M. Wachowicz, Jr. 2008) or ROE = Net Income / Average Total Stockholders' Equity (Wiliams, Susan F, Bettner and Carcello, 2008).

The capital invested in the company is made the basis for measuring the level of success of the company in carrying out its activities. However, in carrying out the activities of the company the funds used are not only sourced from equity but from debt, both short-term debt and long-term debt. Therefore it is necessary to analyze the proportion of debt used in the company; the results of the analysis will reflect the effectiveness of the use of debt. If debt is used effectively, it will support the success of the company, but if the debt is not used effectively, it becomes a burden on the company which ultimately impacts on the company's performance. The proportion of debt with equity is known as the capital structure or capital structure.

The mixture of debt and equity, a business use, is called its capital structure (Libby, Robert, Patricia A. Libby, Daniel G. Short. 2011). Capital structure is a mixture of a firm's long-term debt, short-term debt, common equity and preferred equity. When analysts refer to capital structure, they are most likely to refer to a firm's debt-to-equity (D/E) ratio, the Debtto-Equity Ratio as a Measure of Capital Structure (https://www.investopedia.com/terms/c/ capitalstructure.asp).

With a combination of debt and capital as a source of assets and operational financing, it is expected to provide maximum benefits, because in the source of funds contained costs, both the cost of debt and the cost of equity. Thus, with these assets must generate maximum income to finance debt in the form of interest to the debtor and dividends that must be given to investors. The two sources of financing are described in the chart as follows (Gapenski, Louis C, 2005):

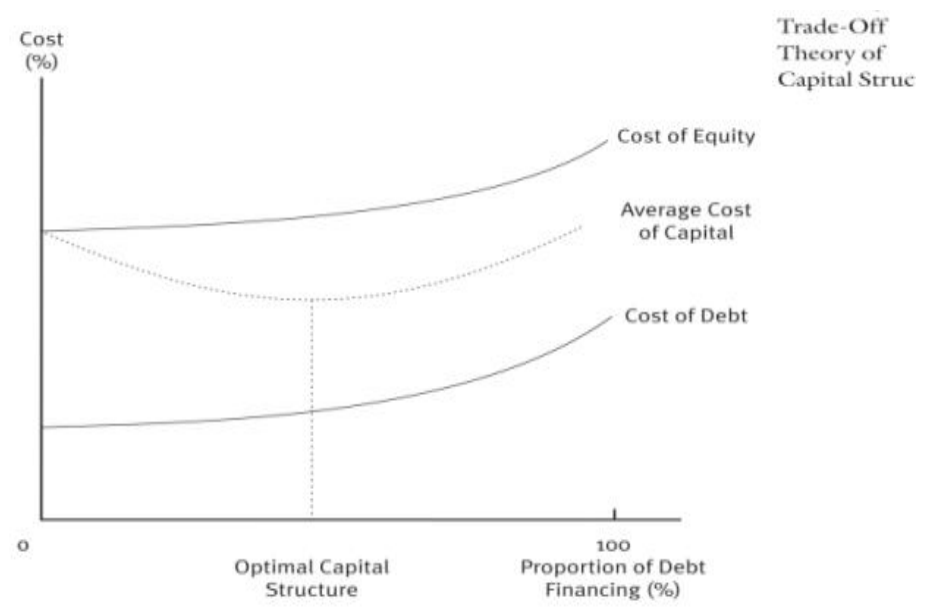

Figure 1 - Trade-Off Theory of Capital Structure

In figure 1 above, shows what is most relevant to the financing decision not only the cost of debt or just the cost of equity but the weighted average cost (combination) of the two components. Weighted average costs are displayed on the chart as dashed lines labeled "average capital costs." At zero debt ( $\mathrm{Y}$ axis), the company is financed by all equity, so the average cost of capital is only the cost of its equity. When a business first starts using debt financing, it adds a lower cost component to its capital structure, and therefore the average cost of financing decreases. However, when the proportion of debt financing increases, both the cost of equity and the cost of debt increase, and at an increasing rate. At some point, increased component costs outweigh the fact that more low-cost debt components are being used, and the average cost of capital outflows. Beyond this point, the cost of average capital starts to increase.

There are four factors that influence decision making Structure capital (Housten and Brigham; 2010): business risk; the firm's tax position; financial flexibility; managerial conservatism or aggressiveness. 


\section{METHODS OF RESEARCH}

The method used in this research is descriptive analysis. Then the variables studied consisted of capital structure as an independent variable and dividend payout ratio as a dependent variable.

The population in this study was all issuers include the category JII70 Index in Indonesia Stock Exchange which consists of 70 listed companies into the list JII70 Index constituents per 28 November 2018. Then the sample of this research is the issuer who met the study criteria as the following:

1. Issuers who distribute dividends in 2016 and 2017.

2. Reporting the Long Term at the end of 2016 and 2017.

Based on the criteria set, out of 70 issuers obtained 34 issuers who meet the criteria set by the researcher consisting of:

Table 1 - Research Subject

\begin{tabular}{|l|l|l|l|l|l|}
\hline No & Code & Emitter & No & Code & Emitter \\
\hline 1 & LPPF & Matahari Dept Store Tbk & 17 & KLBF & Kalbe Farma TBk \\
\hline 2 & LSIP & PP London Sumatra Indonesia Tbk & 18 & KAEF & Kimia Farma Tbk \\
\hline 3 & MAPI & Mitra Adiperkasa Tbk & 19 & JSMR & Jasa Marga (Persero)Tbk \\
\hline 4 & MNCN & Media Nusantara Citra Tbk & 20 & ITMG & Indo Tambangraya Megah Tbk \\
\hline 5 & MYOR & Mayora Indah Tbk & 21 & ISAT & Indosat Tbk \\
\hline 6 & PGAS & Perusahaan Gas Negara Tbk & 22 & INTP & Indocement Tunggal Prakars TBk \\
\hline 7 & PTBA & Bukit Asam Tbk & 23 & INDF & Indofood Sukses Makmur Tbk \\
\hline 8 & RALS & Ramayana Lestari Sentosa Tbk & 24 & ICBP & Indofood CBP Makmur Tbk \\
\hline 9 & SCMA & Surya Citra Media Tbk & 25 & AALI & Astra Agro Lestari Tbk \\
\hline 10 & SIDO & Industi Jamu danFarmasi Sido Muncul Tbk & 26 & ACES & Ace Hardware Indoenesia Tbk \\
\hline 11 & SIMP & Salim Ivomas Pratama Tbk & 27 & ADRO & Adero Energy Tbk \\
\hline 12 & SMBR & Semen Baturaja (Persero ) Tbk & 28 & AKRA & AKR Corporindo Tbk \\
\hline 13 & UNTR & United Tractors Tbk & 29 & AUTO & Astra Otoparts Tbk \\
\hline 14 & UNVR & Unilever Indonesia Tbk & 30 & ASII & Astra International Tbk \\
\hline 15 & WTON & Wijaya Karya Beton Tbk & 31 & BMTR & Global Mediacom Tbk \\
\hline 16 & LINK & Link Net Tbk & 32 & ELSA & Elnusa Tbk \\
\hline
\end{tabular}

Source: IDX Indonesia 2018.

To test used analysis, the authors performed a correlational test to determine whether there are influences and extent of their influence on structure of capital return on return on equity.

To see how far the Traffic models in explaining variations in the dependent variable. The correlation coefficient is between zero and one. The $R^{2}$ means the variables are dependent and explained very limited. A value that is close to independent variables is needed to predict the dependent variables. In general, the cross section is relatively low, while for the data period (Time Series) and time section, usually has a high coefficient determination.

Hypothesis is a temporary solution to the research problem; therefore the formulation of research problems is usually arranged in the form of a question sentence. Testing hypotheses to be done with the author with the following:

Ho1: $\rho=0$ Capital structure does not affect Return on Equity;

Ha1: $\rho \neq 0$ Capital structure affects Return on Equity.

The trust level used in this study was $95 \%$ with a $5 \%$ significance level $(\alpha=0.05)$. It is often used in social science which shows the real two variables correlation.

\section{RESULTS AND DISCUSSION}

Based on the recapitulation of data collected by researchers on the variables of capital structure and return on equity in 2016 and 2017, then the processing is carried out using the SPSS Version 25 program, the results of which are described in table 2 as follows: 
Table 2 - Model Summary

\begin{tabular}{|c|c|c|c|c|c|c|c|c|c|}
\hline \multirow{2}{*}{ Model } & \multirow{2}{*}{$\mathrm{R}$} & \multirow{2}{*}{ R Square } & \multirow{2}{*}{ Adjusted R Square } & \multirow{2}{*}{ Std. Error of the Estimate } & \multicolumn{5}{|c|}{ Change Statistics } \\
\hline & & & & & R Square Change & F Change & df1 & df2 & Sig. F Change \\
\hline 1 &, $425^{\mathrm{a}}$ & , 181 & ,168 & ,2405856 & ,181 & 13,678 & 1 & 62 & ,000 \\
\hline
\end{tabular}

The effect of capital structure on Return on Equity is 0.181 or $18.1 \%$ is significant where $\mathrm{F}$ is calculated $<$ Ftable is $0.00<0.05$ while the influence of other factors on ROE is 0.819 or with an epsilon coefficient of 0.905 . The influence of other factors that affect ROE outside the capital structure is very large; it is possible to influence the management competencies for managing assets.

Then the regression equation from the results of processing the data can be described in table 3 as follows:

Table 3 - Coefficients

\begin{tabular}{|c|c|c|c|c|c|c|c|c|}
\hline \multirow{2}{*}{ Model } & \multicolumn{2}{|c|}{ Unstandardized Coefficients } & \multirow{2}{*}{$\frac{\text { Standardized Coefficients }}{\text { Beta }}$} & \multirow{2}{*}{$\mathrm{T}$} & \multirow{2}{*}{ Sig. } & \multicolumn{3}{|c|}{ Correlations } \\
\hline & B & Std. Error & & & & Zero-order & Partial & Part \\
\hline (Constant) & ,066 & ,048 & & 1,379 &, 173 & & & \\
\hline CS & , 156 & ,042 & ,425 & 3,698 &, 000 & ,425 & ,425 & ,425 \\
\hline
\end{tabular}

a. Dependent Variable: Return On Equity

Table 4 - ANOVA ${ }^{a}$

\begin{tabular}{|c|c|c|c|c|c|c|}
\hline \multicolumn{2}{|c|}{ Model } & Sum of Squares & Df & Mean Square & F & Sig. \\
\hline \multirow{3}{*}{1} & Regression &, 792 & 1 &, 792 & 13,678 &, $000^{\mathrm{b}}$ \\
\cline { 2 - 7 } & Residual & 3,589 & 62 &, 058 & & \\
\cline { 2 - 7 } & Total & 4,380 & 63 & & \\
\hline \multicolumn{6}{|c|}{ a. Dependent Variable: Return On Equity } \\
\hline \multicolumn{6}{|c|}{ b. Predictors: (Constant), Capital Structure } \\
\hline
\end{tabular}

Based on table 3 above, the regression equation that can be made is $Y=0.066+$ $0.156 \mathrm{X}$ and based on Table 4 the regression equation shows significant meaning that the equation is feasible to use. The regression equation shows a positive slope of the mean shows if there is an increase in the capital structure then has an impact on the Return on Equity but this positive effect shows that the use of debt is actually used effectively. This is in accordance with the results of the study Khalid Ashraf CHISTI,Khursheed ALI, Mouh-i-Din SANGMI (2013) Elisabeth Mueller (2002, Abeywardhana, DKY (2015), Abor, Joshua (2005). But it is different from the results of research conducted by Anas Ali Al-Qudah. (2017), Mahfuzah Salim (2012), Mohamed Khalifa M. Tailab (2014), T. Velnampy. \& J. Aloy Niresh (2012), that structure capital has a negative relationship with profitability with the ROE indicator.

\section{CONCLUSION}

Based on the results of the 2016 and 2017 financial statement data processing on JII70 companies with a sample of 32 issuers, capital structure has a positive effect on return on equity, meaning that if the capital structure increases, the return on equity will increase, but this capital structure increase there is a limit because the increase in capital structure is due to an increase in debt. Therefore companies must be able to determine the optimal limit of capital structure; this is illustrated by Gapenski, Louis C, (2005: 395).

\section{REFERENCES}

1. Abeywardhana, DKY 2015. Capital Structure and Profitability: An Empirical Analysis of SMEs in the UK. Journal of Emerging Issues in Economics, Finance and Banking (JEIEFB) An Online International Research Journal. Vol. 4(2). 
2. Ashraf, Khalid Chisti; Khursheed Ali, 2013. Impact Of Capital Structure On Profitability Of Listed Companies (Evidence From India) The USV Annals of Economics and Public Administration Volume 13.

3. Abor, Joshua. 2005. The effect of capital structure on profitability: an empirical analysis of listed firms in Ghana", The Journal of Risk Finance, Vol. 6 Issue: 5, pp. 438-445, https://doi.org/10.1108/15265940510633505.

4. Ali, Anas Al-Qudah. 2017. The Relationship between Capital Structure and Financial Performance in the Companies Listed in Abu Dhabi Securities Exchange: Evidences from United Arab Emirates. Review of European Studies; Vol. 9, No. 2; 2017 ISSN 1918-7173 E-ISSN 1918-7181 Published by Canadian Center of Science and Education

5. Gapenski, Louis C. 2005. Healthcare Finance An Introduction To Accounting And Financial Management. Third Edition: Foundation of the American College of Healthcare.

6. Gitman, Lawrence J. 2000. Principles of Managerial Finance, seventeenth edition. Massachusetts: Addison-Wesley Publishing Company.

7. Khalifa, Mohamed M. Tailab. 2014. The Effect of Capital Structure on Profitability of Energy American Firms. International Journal of Business and Management Invention ISSN (Online): 2319 - 8028, IS SN (Print): 2319-801X.

8. Mueller Elisabeth. 2002. Benefits of Control, Capital Structure and Company Growth. London School of Economics, Department of Economics and Centre for Economic Performance, Houghton Street, London.

9. Libby, Robert, Patricia A. Libby, Daniel G. Short. 2011. FINANCIAL ACCOUNTING Published by McGraw-Hill/Irwin, a business unit of The McGraw-Hill Companies, Inc., 1221 Avenue of the Americas, New York, NY, 10020. Copyright (C) 2011, 2009, 2007, 2004, 2001, 1998, 1996 by The McGraw-HillCompanies, Inc. All rights reserved.

10. Salim, Mahfuzah. 2012. Capital Structure and Firm Performance: Evidence from Malaysian Listed Companies. Published by Elsevier Ltd. Selection and peer-review under responsibility of JIBES University, Jakarta doi: 10.1016/j.sbspro.2012.11.105

11. Van Horne, James C., John M. Wachowicz, Jr. 2008. Fundamentals of Financial Management. Thirteenth edition: published under by Prentice Hall, Inc.

12. Velnampy, T. \& J. Aloy Niresh. 2012. The Relationship between Capital Structure \& Profitability. Global Journal of Management and Business Research Volume 12 Issue 13 Version 1.0 Year 2012 Type: Double Blind Peer Reviewed International Research Journal Publisher: Global Journals Inc. (USA) Online ISSN: 2249-4588 \& Print ISSN: 0975-5853

13. Wiliams, Jan R. Susan F. Haka, Mark S. Bettner and Joseph V. Carcello. 2008. Financial \& Managerial Accounting. The Basis for Business Decision. Published by Mc. Graw Hill/ Irwin. New York NY10020.

14. Electronic Source: https://www.investopedia.com/terms/c/capitalstructure.asp 